\title{
A Comprehensive Review on Fishery Biology of Catfishes
}

\author{
Muhammad Amin (Corresponding author) \\ M. Phil, Department of Zoology, University of Karachi (Pakistan) \\ Tel: 92-342-981-9160_E-mail: aminmuhammad013@yahoo.com
}

Dr. Mohammad Shoaib

Profesor, Department of Zoology, University of Karachi (Pakistan)

Tel: 92-300-222-1321Ｅ-mail: drmshoaib_11273@yahoo.com

Ghulam Nabi

$\mathrm{PhD}$ Scholar, Institute of Hydrobiology

Chinese Academy of Sciences, Wuhan, 430072, China

Tel: 92-345-811-2741Ｅ-mail: ghulamnabiqau@gmail.com

\begin{abstract}
Naveed Ahmed
Ph. D student, center of excellence in Marine Biology University of Karachi (Pakistan) Tel: 92-302-882-2558Ｅ-mail: naveedkhan.aqua@yahoo.com
\end{abstract}

Muhammad Kifayatullah

Ph. D student, Lincoln University College, Malaysia

E-mail: kifayatpharma86@yahoo.co

Received: August 25, 2015 Accepted: September 10, 2015

doi:10.5296/jbls.v7i1.8421 URL: http://dx.doi.org/10.5296/jbls.v7i1.8421 


\section{Abstract}

Cat fish exploit a large diversity of both plant and animal protein, and adapt harsh environmental conditions as they have the ability to take atmospheric oxygen. Marine catfish tolerate a broad range of salinities between Open Ocean and fresh water. The entire catfishes have soft as well as scaleless body, are greatly appreciated by consumers and maintain healthy in both fresh and dried condition. In this review article various aspects of cat fish has been discussed.

Keywords: Catfish, Biology, Harsh Environment, Salinity. Culture

\section{Introduction}

The family Ariidae, comprises of catfish distributed mostly in the hot and tropical waters of both, estuarine and marine habitats (Bleeker, 1862). Castro-Aguirre et al., 1999 considered that the family Ariidae designates a taxonomic grouping of 14 genera of about 120 species, several of them intricate and difficult to recognize for the reason that of their morphological similarity. Betancur, 2003 stated that as a minimum of 150 species have been known. The systematic of Ariidae has not been obvious in the description of the genera and species, mainly those of the Atlantic (Wheeler and Baddokwaya, 1981). It has carried about the incidence and persistence of numerous synonyms (Meek, 1904). The main troubles in identifying species characteristics and monophyletic taxa are owing to the broad geographical allocation of the grouping and on the whole resemblance in the exterior morphology of its species, collectively be short of sufficient specimens in the museum collections (Marceniuk and Menezes, 2007). Therefore, it is essential to test a few of the hypotheses on the nomenclature of the group with genetic techniques, including for occurrence, the partition of the catfish of the genus Ariopsis from those of the Arius Valenciennes group, based on the geography of their allocation. According to the mentioned hypothesis, the genus Ariopsis is found north of the equator whereas the genus Arius is established in the southern hemisphere (Castro-Aguirre, et al., 1999). Kobelkowsky and Castillo-Rivera, 1995 observed the number of pharyngeal teeth in Cathorops melanopus, Ariopsisfelis and Bagremarinus and found that diversities help recognize these species. Bagremarins possess three pairs, Ariopsisfelis two pairs and Cathoropsmelanopus one pair of teeth. Current studies on the morphometry of a few ariid fish have presented obvious indication of the monophyly of this group (Betancur et al., 2004). The karyotypic studies of numerous species of Arridae have been shown for evidences of their phyletic relationships. However, the chromosome analysis evolution revealed in the chromosome records has discovered marvellous karyotype constancy not valuable to construct phylogenetic conclusion about this group (Uribe and Díaz, 2000). Further studies of hereditary characters of protein electrophoresis techniques have been greatly useful to identify variability, to assess interspecific relationships along with diverse fish groups (Ruiz and Uribe, 2003). A different genetic study, based on the series of a $2921 \mathrm{pb}$ fragment of the mitochondrial genome (cytochrome b, ATP synthase 8 and 6, 12S and 16S), and on a $978 \mathrm{pb}$ nuclear fragment, presented a strong phylogenetic scrutiny of this grouping by maximum thriftiness (Betancur, 2003). The latest molecular phylogenies of the New World galeichthyins and Arridae, and planned a general phylogeny of family Arridae, presenting a 
structure for future relative studies and classifications through the evaluation of the mitochondrial series (cytochrome b, ATP synthase 8 and $6,12 \mathrm{~S}$ and $16 \mathrm{~S} \sim 3 \mathrm{~kb}$ ) and a nuclear marker (rag 2, 1 kb) of the sample representing numerous biogeographic zones from the large distribution region of the Arrids (Betancur, 2009a).

\section{Marine Catfishes}

The uniqueness of the catfish is to exploit a large diversity of both plant and animal protein, and adapt harsh environmental effects because, they have the ability to take atmospheric oxygen. Although catfishes are aggressive, and predators. To measure the fish quality, colour, texture, taste and smell are very necessary for good marketing (Losordo et al., 1998; McGee and Cichira, 2000). Marine catfish have been tolerated a broad range of salinities between open ocean and fresh water but their rate in fresh waters is not common and are usually distributed above muddy bottoms, or in cloudy waters (Acero, 2002). Marine catfish are generally oral-brooders, after spawning the male will also take the eggs in his oral cavity till hatching into larvae within a month. The male also carry the young one for more days till to able for survival (Jones, et al., 1978). Huge death of marine catfish was generally recognized to one of three reasons: disease, dangerous algal blooms and or of hypoxia (Wardle, et al., 1998). The marine catfish is a commercially important ground fish found extensively in the coastal waters and formed a significant fishery source of the countryside up to eighties. Its value in the marine fish production and also future prospective. The (CMFRI) central marine fisheries research institute was kick off a research scheme in seventies and frequently observed the fishery, biology along with stock distinctiveness for growing executive plan. The catfish production in India proved a constantly declining drift with the zenith in 1982 $(67,666 \mathrm{t})$ and the dip in $1992(36,165 \mathrm{t})$. The yearly average catfish grasp in the pre-mechanized time was smaller number than $20,000 \mathrm{t}$. The large extent mechanization in 1971- 1980 observed a climb in the landings to the tune of 51,271 t followed by the reward seine fishing in Karnataka and Kerala which was further increased the landings to 57,860 t in 1981-1985 era, subsequently lengthy the production bit by bit turn down to 40,008 $\mathrm{t}$ in 1991-1995. The former estimate of prospective yield of catfishes had 310,000 t (George et al., 1977). The extremely unstable potential estimate ended throughout diverse era of time together with declining landing developments imposes the achievement of proper management strategies. During the previous 4 decades catfish fishery was seriously analysed to prevent over utilization crisis and also conserve the endangered species to avoid further degradation (Menon, et al., 1996). The reproduction, shoaling and migration behaviour of numerous species of marine catfishes subjected to overexploitation. Species such as $T$. serratus, T. dussumieri and T. tenuispinis although exhibit shoaling behaviour and upright and horizontal migration particularly throughout their adult and spawning phases of life. The entire species have low fecundity ranging from 25 - 190 ova along with a single spawning per year. Parental cares are well developed with the male carrying the brood along with 25 - 120 eggs in the oral- cavity up to 2 months until the young ones are released and live and feed on the shallow muddy grounds (Lakshml and Srinivasa, 1992). The breeding migration toward the shore, the low fecundity, buccal incubation is the biological and behavioural characteristics related to their survival against fishing mortality. The marine catfishes show 
diurnal vertical migration (Rao, et al., 1977) and horizontal migration towards the coast throughout monsoon (James et al., 1989).

\section{Fisheries and Biological Aspects of the Arius Species}

The fish biology has numerous isolated disciplines, such as to study morphology and the mode of life of the organism. The size as well as shape is basics to the examination of differences in living organisms and morphological discrepancy even in the alike species mainly frequently connected to the diverse environmental factors. The length-weight relationship (LWR) is an extremely significant parameter to know the fish population growth and dynamics. Length and weight records are valuable standard consequences of every fish sampling scheme (Morato, et al., 2001). LWR of fishes are significant in fisheries biology since they permit the judgment of the standard weight of fish of a known length grouping by launching a numerical relation between the two factors (Beyer, 1987). The LWR is predominantly essential in factorizing yield equations as well as in assessments of stock pile size (Abdurahiman, et al., 2004). The accurate association between length and weight be different among species of fish according to their innate body contour, and also within a species according to the condition of individual fish (Schneider, et al., 2000). A study on the morphometric characters of fishes is vital since they be able to be used in favour of the discrimination of taxonomic units (Ambily and Nandan, 2010). The condition factor in fisheries science is used in sort to evaluate the condition "stoutness" or wellbeing of catch fish (Ahmed et al., 2011). The condition factor generally rises through sexual maturation. The study of the biology of spotted catfish (Arius maculatus) in Malaysian water is still scant. Mohsin, and Ambak, 1996 briefly described the common biology of the species samples purchased from fish marketplace throughout Malaysia. Consistent studies at the chosen neighbouring environs are to be completed in the future. The Malaysian spotted catfish are mostly oceanic or salty water and sporadically go into the freshwater during flooding tides. This spotted catfish is well sprinkled in tropical as well as in subtropical waters all over the continents (Linden, 1998). The studies on the eco-biology and systematic of the sea catfish families in Tropical Asian waters required to be redrafted over time, because ambiguity defined as of its newest systematic classification. The length and weight relationship along with relative condition factor Kn of the Arius subrostratus from Champakkara salty water were calculated by test of 392 specimens collected throughout June to September 2008. These fishes ranged from 6 to $29 \mathrm{~cm}$ in TL with 5.6 to $218 \mathrm{~g}$ in TW. The mean (Kn) values ranged from 0.75 to 1.07 for males, 0.944 to 1.407 for females and 0.96 to 1.196 for pooled sexes. The length and weight relationship and relative condition factor $(\mathrm{Kn})$ explained that the health of the A. subrostratus is tremendous. The morphometric measurements of the species were produced to be non-linear and no significant dissimilarities were observed between the two sexes (Ambily, and Nandan, 2010). The intra-specific disparity in morphology of the domestic catfish Arius jella (Ariidae) was studied inside five estuarine environs in Sri Lanka. Five of the morphometric characteristics to describe the shape of $A$. 
jella were significantly lengthy dissimilar among various places. In more characteristics, significant dissimilarity was found representing morphological heterogeneity. The results assign a slight grade of spatial separations in morphology within A. jella of the studied in estuarine neighbourhoods (Gunawickrama, 2007). Before frequent in the rivers and streams of Bangladesh, their populations have badly turn down owing over misuse of different ecological alteration and destroying of the natural habitation (Hossain, et al., 2012a). The length and weight relationship of two main catfishes, Arius caelatus and A. tenuispinis from of the Mumbai waters has been shown that there is no significant variation in growth between sexes for both the species . The study presented that isometric growth has occurred in A. caelatus and A. tenuispinis (Sawant, 2013). The marine Catfishes belong to family Tachysauridae comprise approximately $2.3 \%$ of the annual landings of marine fishes and $13.6 \%$ of overall demersal fish of India landing throughout 2008 (Anon Annual Report, 2009). The marine catfish resources are scattered all over the Indo-West Pacific area, of west coastal line of India toward Bangladesh, Myanmar, Indonesia, Malaysia, Brunei and Pakistan. Catfishes had produced very important seasonal fisheries all along the east and west of west coastal line of India as early artisanal times, although had rarely been observed since everything more than of limited significance. By the beginning of regular fishing mostly trawling on a massive scale, a brutal change was happened in the misuse pattern of the demersal resources along with the marine catfishes carried to the front position. The fishery of Catfish is also significant alongside of the Maharashtra shoreline and in a dozen of the catch species landed in the Mumbai of them A. tenuispinis and Arius caelatus are more significant. The distinctive behavioural characteristics in the incubating male of marine catfishes all over the spawning season, arriving coastal waters exposed them more to destructive tools like trawlers so there is a serious need to watch the condition of resources of catfish regularly. Length and weight relationship is one of the foremost parameters which provide the weight approximate at a certain length or vice versa. Because it shows the health condition index (Anderson and Gutreuter, 1983; Petrakis and Stergiou, 1995) and the species life history between localities and over time be able to compare. The length-weight relationship of Catfishes collected from Indian waters consists of Tachysurus thalassinus of Waltair and Mandappam were studied (Mojumder, 1971; Menon, 1979). According to the different species of marine catfishes, the length weight relationship along with age and growth of Arius Arius in parangipettai coast of Tamil Nadu were studied. The length groups were shown the significant with the exception of the length groups 6-9 and 21-24 cm. The b values in the length-weight relationships $\mathrm{W}=\mathrm{aLb}$ ranged from 3.1031 to 5.0423 and $\mathrm{R}^{2}=0.9335$ to 0.9818 . By counting the total blood cell, reveals rising in number as in length groups increasing. It has been shown that the fish of the 6-9 cm size contains lowest number of blood cells and maximum number were occurred in 30-33 cm size fishes (Balamurugan, 2013). There were collected 184 fishes of Arius tenuispinis from Bengal Bay. The condition factor $(\mathrm{K})$ and relative condition factor $\left(\mathrm{K}^{\wedge}\right)$ mean values observed in male were, 1.0755 and 1.0144 in total length-weight and 1.7806 and 1.0005 in standard length-weight relationship while in female, 1.0307 and 1.0025 in total length weight and 1.8148 and 1.0031 in standard length-weight relationship likewise (Das, et al., 1997).

\section{Reproduction and Recruitments}


It has been observed that the species of commercially important marine catfishes are under brutal fishing pressure except Osteogenieosus militaris (CMFRI, 1987). Since the fishing pressure effects on catfish stocks have created the major threat. The factors which affect the habitat and reduce the prey abundance, like breeding migration, low down fecundity, buccal incubation and ceaseless bottom trawling have also declined catfish landings (Menon, 2004). The number of males catfishes, decreased in larger group, namely Tachysurus tenuispinis (Arius tenuspinus day, 8177), T. thalassinus (Arius serratus day, 1877), T. caelatus, T. jella and $O$. militaris when studied for sex differentiation, length, fecundity and ova size. They are fractional spawners contain both unripe and ripe ova in the same ovaries and the number of ripe eggs in the male oral cavity are less than that of the ovary in the female. The males are more subjected to fishing owing to gestation deeds (Raje, and Vivekanandan, 2008). In Malaysia little is known on the marine catfish population biology and reproductive biology of the Aridae fish species. Morphometric and meristic characteristics of the five species of Arius of Kedah coastal water and population dynamics of $O$. militaris off of penang coastal water were studied (Mansor, et al., 2012a). The study of Reproductive approach and fecundity was very essential to estimate the fish reproductive potential (Murua, et al., 2003). The study of the gonadosomatic index had a great significance to know the gonad dynamics and also used as an indicator of the spawning period (De Vlaming, et al., 1982). The slow alteration occurs in the gonads during ripening had shown by macroscopic study of the gonads (De and Lau, 1999). It was investigated that the Arius maculates only breed one time a year from January to April off the Bombay coast and from September to October in India off the Karnataka coast (Jeyaseelan, 1998). The spawning approach was cyclic, and fish breed only once a year the Arius maculates reproduction is dioecism fertilization occurred externally the males incubate the eggs in the oral cavity and start starvation to swallow one or two eggs to regulate basal metabolism. The newly hatched embryos feed on inhaled particles of the females (Balon, 1990). It is very important to get knowledge about fishery biology and nurture of fishes both in natural water and in aquaculture. The knowledge of the fecundity is very essential for fish life history (King, 1997).

\section{Edible Value of the Arius Species}

Catfishes are extraordinarily essential marketable and greatly appreciated fishes (Olokor, et al., 2011). They enjoy customers fondness (Holden and Reed, 1972) adjustable to unfavourable ecological circumstances, resistant to illness, accept economical nourish to increase and have prompt development rate (Olufeagba, 1996). Chrysichthys nigrodigitatus, color is grayish-blue, is limited to the base of profound water, omnivorous; eat bivalves, detritus, crustaceans, chironomid and vegetable matter (Bankole, et al., 2011). This fish be capable of increasing in equally fresh and salty water environments. Clarias gariepinus of the family Clariidae, has a giant elongated head along with the body is $3.1-3.88$ times the head with 52-62 rays. This omnivorous catch fish covers a high profitable price in the market particularly on the beginning of arid season (Ime and Fakunle, 2007). Heterobranchus bidorsalisis of this family has a lengthen fish with a big, granulated along with depressed head. (Marioghae, 1991). The entire catfishes have soft as well as scaleles body, are greatly appreciated by consumers and maintain healthy in both fresh and dried condition. The 
financial significance of catfishes such like Clariasand Heterobranchus also supports the species` intergeneric hybridization (Ezenwa, 1985).

\section{Conclusion}

Catfish is a good candidate for fish farming as it is capable to survive in harsh environmental conditions and is resistant to illness. Further, it has soft and scaless bodies that attract consumers. It also supports the species` intergeneric hybridization. Therefore, in developing countries Catfish farming can easily fulfil the need for meat.

\section{References}

Abdulrahiman, K. P., Harishnayak, T., Zacharia, P. U. and Mohamed, K. S. (2004). Length weight relationship of commercially important marine fishes and shellfishes of the southern coast of Karnataka, India, NAGA, World Fish Center Quarterly, 271 and 2: adaptation. $J$. Fish Biol., 43(Supplement A), 53-73.

Acero, A. (2002). Ariidae: sea catfishes. Pages 831-852. In: The living marine resources of the western central Atotal lengthantic. Volume 2. Bony fishes part 1 (Ascipenseridae to Grammatidae), K.E. Carpenter, editor. FAO Species Identification Guide for Fishery Purposes, American Society of Ichthyologists and Herpetologist Special Publication 5. Rome.

Ahmed, E. O., Ali, M. E., \& Aziz, A. (2011). Length-Weight Relationships and Condition Factors of Six Fish Species in Atbara River and Khashm El- Girba Reservoir, Sudan. International Journal of Agriculture Sciences, 3(1), 65-70.

Ambily, V., \& Nandan, S. B. (2010). Length-weight relationship, relative condition factor (Kn) and morphometry of Arius subrostratus (Valenciennes, 1840) from a coastal wetotal lengthand in Kerala. Indian J. Fish., 57(4), 39-44.

Anderson, R., Gutreuter, S. J. (1983). Length-weight, and associated structural. Indices. In: L. Nielsen and D. Johnson (Eds.) (Fisheries Techniques. American Fisheries Society, Bethesda, Maryland), 283-300.

Anon Annual Report, (2009). Central Marine Fisheries Research Institute, Cochin. 133p.

Balamurugan, S. (2013). Length-Weight Relationship, Age and Growth of Wild Catfish Arius Arius (Hamilton, 1822) In Parangipettai East Coast Of Tamil Nadu. An International Journal of Marine Sciences Thalassas, 29(1), 17-23.

Balon, E. K. (1990). Epigenesis of an epigeneticist: the development of some alternative concepts on the early ontogeny and evolution of fishes. Guelph Ichthyology Reviews, 1, 1-48.

Bankole, N. O, Yem I. Y., \& Olowosegun, O. M. (2011). Fish Resources of Lake Kainji, Nigeria. In: Raji A Okaeme N. and Ibeun MO (Eds.). Forty Years on Lake Kainji Fisheries Research, NIFFR, New Bussa, Nigeria, 20-42.

Betancur, R, R., Acero, A., \& Mejía-Ladino, L. M. (2004). Sistemática filogenética 
preliminar de algunos bagres marinos (Siluriformes: Ariidae) neotropicales [Preliminary phylogenetic analysis of some Neotropical sea catfishes (Siluriformes: Ariidae)]. Memoria de la Fundación La Salle de Ciencias Naturales, 158, 61-85.

Betancur, R. R. (2003). Filogenia de los bagresmarinos (Siluriformes: Ariidae) del Nuevo Mundo. Tesis de Maestría en Ciencias, Universidad Nacional de Colombia-INVEMAR, Bogotá.121 p.

Betancur, R. R. (2009a). Systematic and evolutionary history of sea catfishes (Siluriformes: Ariidae). Ph.D. Dissertation, Auburn University, Auburn.200 p. Duffus JH. Environmental Toxicology. Resource and Environmental Science series, Edward Arnold Publishers London, England. 1980. 164.

Beyer, J. E. (1987). On length - weight relationships. Part 1: Computing the mean weight of the fish of a given length Class. Fishbyte, 5, 11-13.

Castro-Aguirre, J. L., H. S. Espinosa, \& Schmitter-Soto, J. J. (1999). Ictiofauna Estuarino-Lagunary Vicaria de México. Colección Textos Politécnicos. Serie Biotecnologías. Ed. Limusa. México, D.F. pp. 140-158, 521-532

CMFRI, (1987). Marine catfish resources of India: exploitation and prospects. Bull. Cent. Mar. Fish. Res. Inst., 40, 1-94.

Das, N. G., Majumder, A. A., \& Sarwar, S. M. M. (1997). Length - weight relationship and condition factor of Catfish Arius tenuispinis, Day, 1877. Indian. J. Fish., 44(1), 81-85.

De Martini, E. E., \& Lau, B. B. (1999). Morphometric criteria for estimating sexual maturity in two snappers, Etelis carbunculus and Pristopomoides sieboldii", Journal of Fish Biology 97, 449-458.

De Vlaming, V. L., Grossman, G. R., \& Chapman, F. (1982). On the use of the gonado somatic index", Comparative Biochemistry and Physiology, 73A(1), 31-39.

Ezenwa, B. (1985). Culturable fish seed in Nigerian Water, a research note on Swamp Fisheries Management. Min. of Agric. Kaduna, p.17.

George, P. C. B. T. Antony Raja \& George, K. C. (1977). Fishery resources of the Indian Economic Zone. Souvenir. IFP. Cochin, 79-116.

Gunawickrama, K. B. S, (2007). Morphological heterogeneity in some estuarine populations of the catfish Arius jella (Ariidae) in sri lanka. Cey. J. Sci. (Bio. Sci.) 36(2), 100-107.

Hossain, M. Y., Rahman, M. M., Fulanda, B., Jewel, M. A. S., Ahamed, F., Ohtomi, J. (2012a). Length-weight and length length relationships of five threatened fish species from the Jamuna (Brahmaputra River tributary) River, northern Bangladesh. J. Appl. Ichthyol. 28, 275-277.

Ime-Ibanga, U., Fakunle, J. O. (2007). Proximate composition and amino acids profile of smoked catfish Clarias gariepinus and Tilapia Oreochromis niloticus. In :Araoye PA, Adikwu IA and Banke ROK. (Eds.). Proc. of $22^{\text {nd }}$ Annual Conf. of Fisheries Soc. of Nigeria, Kebbi, 
Nov.12-16, 2007, pp. 91-95.

James, P. S. B. R., Bande, V. N., Gopinatha, M. N., \& Balachandran, K. (1989). The catfish resources of southwest coast of India: Prospects and Management problems. Bull. Cent. Mar. Fish. Res. Inst., 44(1), 78-94.

Jeyaseelan, M. J. P. (1998). Manual of fish eggs and larvae from Asian mangrove waters. United Nations Educational, Scientific and Cultural Organization. Paris. 193.

Jones, P. W., Martin, F. D., \& Hardy, J. D. Jr. (1978). Development of fishes of the mid-Atotal lengthantic Bight: an atotal lengthas of egg, larval, and juvenile stages. Volume I: Acipenseridae through Ictaluridae. U.S. Fish and Wildlife Service, Office of Biological Programs. FSW/OBS-78/12. Ft. Collins, CO. 366 pp.

King, R. P. (1997). Weight-fecundity relationships of Nigerian fish populations. NAGA, the ICLAR Mquarterly, 22(1), 33-36.

Kobelkowsky, D. A., \& M. Castillo-Rivera. (1995). Sistema digestivoy alimentaciónde los bagres (Pisces: Ariidae) del Golfo de México. Hidrobiológica, 5(1-2), 95-103.

Lakshmi, K., \& Srinivasa, R. K. (1992). Trends in catfish catches at Visakhapatnam showing disappearance of Arius tenuispinis. J. mar. biol. Ass. India, 34(1 and 2), 26-37.

Linden, R. (1998). The Catfishes of Asia: Chacidae. Newsletter, Northern Area Catfish Group. Issue No., 3, 3-6.16.

Losordo, T. M. Masser, M. P. Rakocy, J. (1998). Recirculating aquaculture tank production systems. An overview of critical considerations. South regional aquaculture centre. Publication No. 451.

Mansor, M. I., Nur-Syazwani, R., Siti-Azizah, M.-N., \& Khairun, Y. (2012a). Morphological and meristics characteristics of estuarine catfish (Siluriformes: Ariidae) from Merbok Estuary, Kedah, Malaysian Fisheries Journal (in press).

Marceniuk, A. P., \& N. A. Menezes. (2007). Systematic of the family Ariidae (Ostariophysi Siluriformes), with a redefinition of the genera. Zootaxia 1416, 1-126.

McGee, M. Cichira, C. (2000). Principles of water recirculating and filtration in aquaculture. University of Florida. Department of fisheries and aquatic sciences. FA.

Meek, S. E. (1904). The Fresh Water Fishes of Mexico North of the Isthmus of Tehuantepec. Publication Field Columbian Museum Zoological Series, 5, 1-252.

Menon, N. G. (1979). Studies on the biology and fishery of giant marine catfish. Tachysurus thalassinus (Ruppell) Ph.D. thesis, University of Cochin, (unpublished).

Menon, N. G. (2004). Catfishes. In: Mohan Joseph, M. and Jayaprakash, A. A. (Eds). Status of Exploited Marine Fishery Resources of India. CMFRI, Kochi, 110-119.

Menon, N. G., K. Balachandran, S. G. Raje, P.U. Zacharla, M.Feroz Khan. Y. Appanna Sastry \& P. Jayasankar. (1996). Catfish resource in the Indian shelf waters. Proc. Second workshop 
on scient. resul. of FORV Sugar Sampada. 305 -314.

Mohsin, A. K. M., \& M. A. Ambak. (1996). Marine fishes and fisheries of Malaysia and neighbouring countries. University of Pertanian Malaysia Press, Serdang, Malaysia, 744.

Mojumder, P. (1971). Length-weight relationship in catfish, Tachysurus thalassinus (Ruppell). Indian J. Fish., 18, 179-182.

Morato, T., P. Afonso, P. Loirinho, J. P. Barreiros, R. S. Sanstos \& R. D. M. Nash. (2001). Length-weight relationships for 21 costal fish species of the Azores, North-eastern Atotal lengthantic. Fisheries Research, 50, 297- 302.

Murua, H., Kraus, G., Saborido-Rey, F., Witthames, P. R., Thorsen, A., \& Junquera, S. (2003). Procedures to estimate fecundity of marine fish species in relation to their reproductive strategy. Journal of Northwest Atotal lengthantic Fishery Science, 33, 33-54.

Olokor, J. O, Ihuahi, J. A., Omojowo, F. S., Ugoala, E. R., Ngwu, E. O., \& Adelowo, E. O. (2011). Fish Handling, Processing and Preservation in Kainji Lake Area of Nigeria. In: Raji A., Okaeme A.N. and Ibeun M.O.(Eds.). Forty Years of Lake Kainji Fisheries Research. National Institute for Freshwater Fisheries Research (NIFFR), New Bussa, Nigeria, pp.71-103.

Olufeagba, S. O. (1996). Embryogenesis of Heterobranchus longifilis (Lourier and Valenciennes 1840). Paper presented at the Fisheries Society of Nigeria Conference.

Petrakis, G., \& Stergiou K. I. (1995). Weight-length relationships for 33 fish species in Greek waters. Fish. Res. 21, 465-469.

Raje, S. G., \& Vivekanandan, E. (2008). Vulnerability of catfish to fishing: an investigation based on the landings at Mumbai. Indian J. Fish., 55(3), 227-233.

Rao, K. V. N., M. Kumaran and J. Sankarasubramanlam. 1977. Resources of rlbbonflshes and catflshes off the southwest coast of India. Seafood Export J. 9(11): 9-26.

Ruiz-Carus, R., \& M. Uribe-Alcocer. (2003). Phylogenetic assessment of Eucinostomus gula, Eugerres plumieri and Diapterus auratus (Gerreidae: Pisces) based on allozyme and mtDNA analyses. Caribbean Journal of Science, 39(1), 109-115.

Sawant, B. T. (2013). Comparative length-weight relationship of two species of catfishes, Arius caelatus (Valenciennes, 1840) and Arius tenuispinis (Day, 1877) from Mumbai waters ${ }^{+.}$ Indian Journal of Geo-Marine Sciences Vol. 42(2), pp.266-269.

Schneider, J. C., P. W. Laarman \& H. Gowing. (2000). Chapter 17: Length-Weight Relationships. Manual of Fisheries Survey Methods II.

Uribe-Alcocer, M., \& P. Díaz-Jaimes. (2000). Fish chromosomes as biomarkers of genotoxic damage and proposal for the use of tropical catfishspecies for short-term screening of genotoxic agents. In: Butterworth F. M., A. Gunatilaka and M. E. Gonsebatt (Eds.) Biomonitors and Biomarkers as Indicator of Environmental Change. Vol. II. Plenum Press, NY. 361-390. 


\section{Macrothink}

Wardle, W. J., Denton, W. G., Harper, D. E., Jr. (1998). An Account of the 1994 Phytoplankton Blooms and Mass Mortalities of Marine Animals along the Western Louisiana and Northern Texas Coast, with Comparison to Similar Events of 1984. Pp 33-38. In: Characteristics and causes of Texas marine strandings. U.S. Department of Commerce, R. Zimmerman (ed.). NOAA Tech. Rep. NMFS, 143, 85.

Wheeler, A., \& A. Baddokwaya. (1981). The generic nomenclature of the marine catfishes usually referred to the genus Arius (Osteichthyes: Siluriformes). Journal of Natural History, 15(5), 769-773. 